\title{
Bionomics of the oriental latrine fly Chrysomya megacephala (Fabricius) (Diptera: Calliphoridae): temporal fluctuation and reproductive potential
}

Narin Sontigun ${ }^{1,2}$, Kabkaew L. Sukontason², Tunwadee Klong-klaew², Sangob Sanit ,2, Chutharat Samerjai ${ }^{1,2}$, Pradya Somboon ${ }^{2}$, Sa-nguansak Thanapornpoonpong ${ }^{3}$, Jens Amendt ${ }^{4}$ and Kom Sukontason ${ }^{2 *}$

\begin{abstract}
Background: Chrysomya megacephala is a blow fly species of medical and forensic importance worldwide. Understanding its bionomics is essential for both designing effective fly control programs and its use in forensic investigations.

Methods: The daily flight activity, seasonal abundance related to abiotic factors (temperature, relative humidity and rainfall) and reproductive potential of this species was investigated. Adult flies were sampled twice a month for one year from July 2013 to June 2014 in three different ecotypes (forest area, longan orchard and palm plantation) of Chiang Mai Province, northern Thailand, using semi-automatic funnel traps. One-day tainted beef offal was used as bait.

Results: A total of 88,273 flies were sampled, of which 82,800 flies (93.8\%) were caught during the day (from 06:00 to 18:00 h); while 5473 flies (6.2\%) were caught at night (from 18:00 to 06:00 h). Concurrently, the abundance of $C$. megacephala was higher in the forest area $(n=31,873 ; 36.1 \%)$ and palm plantation $(n=31,347 ; 35.5 \%)$, compared to the longan orchard $(n=25,053 ; 28.4 \%)$. The number of females was significantly higher than that of males, exhibiting a female to male sex ratio of 2.36:1. Seasonal fluctuation revealed the highest abundance of $C$. megacephala in summer, but low numbers in the rainy season and winter. Fly density was significantly positively correlated with temperature, but negatively correlated with relative humidity. No correlation between numbers of $C$. megacephala with rainfall was found. Activity occurred throughout the daytime with high numbers from 06:00 to 18:00 $\mathrm{h}$ in summer and 12:00 to 18:00 $\mathrm{h}$ in the rainy season and winter. As for the nocturnal flight activity, a small number of flies were collected in summer and the rainy season, while none were collected in the winter. Dissection of the females indicated that fecundity was highest during the rainy season, followed by winter and summer.
\end{abstract}

Conclusions: Since the assessment of daily, seasonal activity and the reproductive potential of $C$. megacephala remains a crucial point to be elucidated, this extensive study offers insights into bionomics, which may be considered for integrated fly control strategies and forensic entomology issues.

Keywords: Chrysomya megacephala, Daily flight activity, Seasonal fluctuation, Reproductive potential, Thailand

\footnotetext{
*Correspondence: kom.s@cmu.ac.th

${ }^{2}$ Department of Parasitology, Faculty of Medicine, Chiang Mai University,

Chiang Mai 50200, Thailand

Full list of author information is available at the end of the article
}

(c) The Author(s). 2018 Open Access This article is distributed under the terms of the Creative Commons Attribution 4.0 International License (http://creativecommons.org/licenses/by/4.0/), which permits unrestricted use, distribution, and reproduction in any medium, provided you give appropriate credit to the original author(s) and the source, provide a link to the Creative Commons license, and indicate if changes were made. The Creative Commons Public Domain Dedication waiver (http://creativecommons.org/publicdomain/zero/1.0/) applies to the data made available in this article, unless otherwise stated. 


\section{Background}

The oriental latrine fly, Chrysomya megacephala (Fabricius, 1794), is a medically and forensically important blow fly species as its habit and breeding places are within or near to human settlements. Adults are mechanical carriers of a range of pathogens [1-3] and their larvae can cause myiasis in humans and animals $[4,5]$. The larvae feed on human corpses, thus they can be beneficial in forensic investigations for estimating the minimum time since death $\left(\mathrm{PMI}_{\min }\right)$ [6]. Chrysomya megacephala is considered to be the predominant species associated with human corpses in a forensic context in Thailand and Malaysia [7, 8].

Geographically, C. megacephala expands worldwide, being present in Asia, Australasia/Oceania, and the Palaearctic, Afrotropical, Nearctic and Neotropical realms [9]. This species is considered to have variable habitats, and in addition to human settlements, have been found across different ecotypes, spanning urban, peri-urban, rural and natural forested areas, and found as high up as $2667 \mathrm{~m}$ above sea level [10, 11]. In Thailand, $C$. megacephala was the most abundant blow fly species collected during fly surveys [12, 13] and it was the most important species found on human corpses [7]. Adults are reported as a predominant mechanical carrier of a range of pathogenic bacteria (e.g. Escherichia coli O157:H7, Klebsiella pneumoniae, Salmonella typhi, Staphylococcus aureus, Pseudomonas aeruginosa) and fungi (e.g. Aspergillus spp., Cladosporium spp., Fusarium spp., Curvularia spp.) that can produce diseases such as diarrhea and skin infection in humans [14-16]. Therefore, detailed information on the bionomics of this species is crucial for designing an effective management and improving its consideration in forensic entomology investigations in various environmental habitats. Information such as daily activity, seasonal fluctuation and reproductive potential are vital in this regard.

Several environmental factors, e.g. altitude, rainfall, temperature, relative humidity and land use types can directly affect the distribution and abundance of blow flies $[11-13,17]$. In Thailand, the seasonal activity of C. megacephala has been investigated in Chiang Mai Province, the northern region [12, 18], and Bangkok Province, the central region [19], while the daily activity pattern of $C$. megacephala has only been reported in Bangkok [20]. Considering that different fly activity can affect their ability as a vector, our aim was to investigate the bionomics of C. megacephala, highlighting daily and seasonal activity patterns of the flies in relation to abiotic factors (temperature, relative humidity and rainfall) and ecotypes in Chiang Mai Province, and evaluating the reproductive potential of field collected females.

\section{Methods}

\section{Study area}

This study was conducted at Mae Hia Agricultural Research, Demonstrative and Training Center, located in Mueang Chiang Mai District, Chiang Mai Province, northern Thailand (Fig. 1a). Based on their topography, three different ecotypes were chosen as studied sites, comprising a forest area $\left(18^{\circ} 46^{\prime} 01.08^{\prime \prime} \mathrm{N}, 98^{\circ} 56^{\prime} 08.3^{\prime \prime} \mathrm{E}\right.$; altitude $344 \mathrm{~m})$, a longan orchard $\left(18^{\circ} 45^{\prime} 56.66^{\prime \prime} \mathrm{N}, 98^{\circ}\right.$ $55^{\prime} 40.13^{\prime \prime} \mathrm{E}$; altitude $\left.374 \mathrm{~m}\right)$ and a palm plantation $\left(18^{\circ}\right.$ $45^{\prime} 27.841 " \mathrm{~N}, 98^{\circ} 55^{\prime} 48.515^{\prime \prime E}$; altitude $330 \mathrm{~m}$ ) (Fig. 1b). According to the Thai Meteorological Department report, the climate is divided into three seasons based on rainfall and air temperature values, namely summer (March to May), rainy season (June to October) and winter (November to February).

\section{Fly collection}

Adult fly sampling was performed twice a month for 1 year from July 2013 to June 2014 using semi-automatic funnel traps. The collection procedure was described previously by Klong-klaew et al. [13]. Each trap was baited with $300 \mathrm{~g}$ of 1-day tainted beef offal [12], which was put in a plastic container and placed at the base of the trap. Sampling took place for $24 \mathrm{~h}$ for each experimental cycle. At each study site, 5 traps were set to operate at 5 different time intervals, respectively, including 06:00 to 09:00 h (early morning), 09:00 to 12:00 h (late morning), $12: 00$ to $15: 00 \mathrm{~h}$ (early afternoon), $15: 00$ to $18: 00 \mathrm{~h}$ (late afternoon) and 18:00 to 06:00 h (night). These traps were arranged in a straight line, $50 \mathrm{~cm}$ apart from each other. After the sampling period of $24 \mathrm{~h}$, the fly net was manually removed from the trap, sealed with masking tape to prevent the flies from escaping, labeled and then transported to the laboratory at Department of Parasitology, Chiang Mai University. During the period of this experiment, hourly temperature $\left({ }^{\circ} \mathrm{C}\right)$ and relative humidity (\%) were recorded at each study site on the day of the fly collection using temperature and humidity loggers (EBI 20-TH1; ebro Electronic GmbH \& Co. KG, Ingolstadt, Germany). The average monthly air temperature, relative humidity and rainfall from July 2013 to June 2014, and the daily sunrise and sunset times for the experimental periods, were obtained from the Northern Meteorological Center, situated in Chiang Mai International Airport (18 46'16.8"N, 98 59'00.1"E; altitude $314 \mathrm{~m}$ ), Mueang Chiang Mai District, Chiang Mai Province.

\section{Fly identification}

In the laboratory, all trapped flies were frozen at $-20{ }^{\circ} \mathrm{C}$ for $2 \mathrm{~h}$. They were then identified individually into species under a dissecting microscope (Olympus, Tokyo, Japan) using the taxonomic identification key of Kurahashi \& 
a

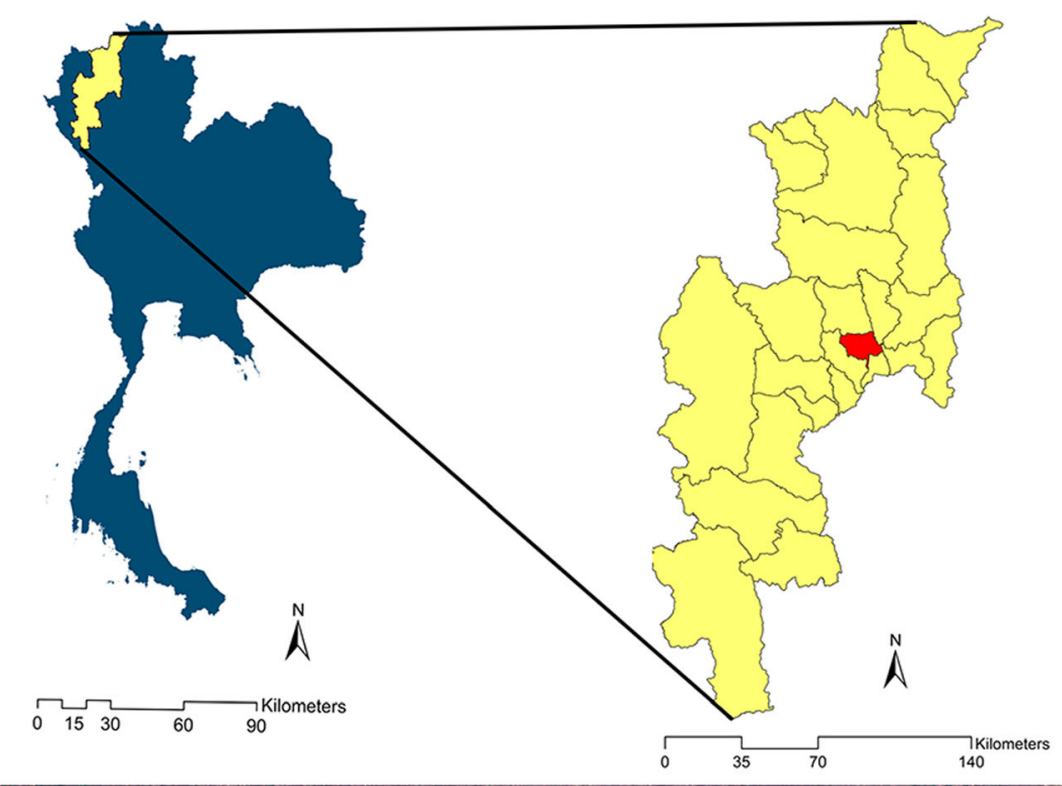

b

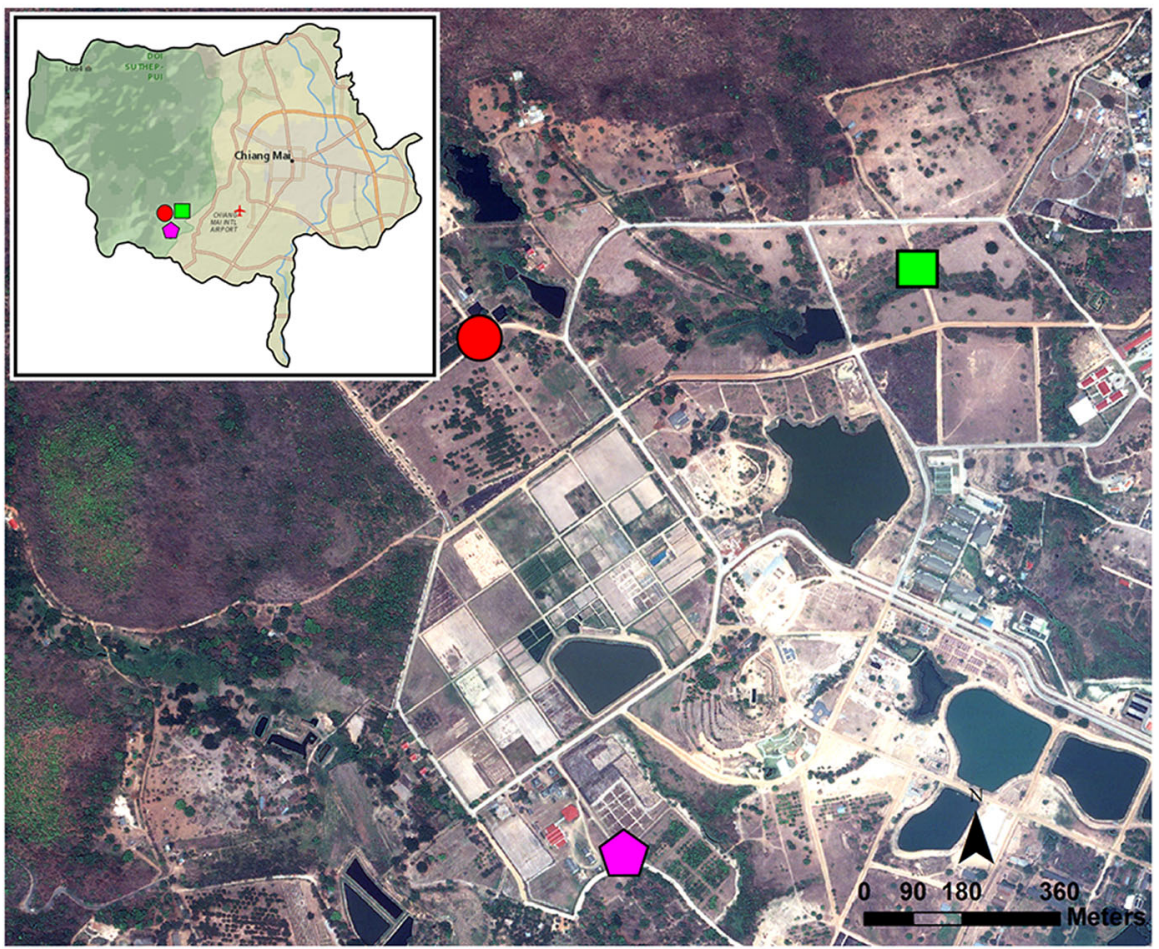

Forest area $O$ Longan orchard $\triangle$ Palm plantation

Fig. 1 Location of the study area. a Map of Thailand showing the study site located in Mueang Chiang Mai District of Chiang Mai Province, northern Thailand. b Satellite imagery of the study area comprising three ecotypes: forest area, longan orchard and palm plantation

Bunchu [21]. Only C. megacephala was sexed, counted and analyzed in this study.

\section{Reproductive status and fecundity of C. megacephala} females

The ovaries of C. megacephala were individually dissected on a glass slide in phosphate buffer saline $(\mathrm{pH}$
7.4) under a dissecting microscope (Olympus) to determine ovarian status (non-gravid or gravid) and parity status (nulliparous or parous) for the differentiation between young and old females. If the number of captured specimens were greater than 100, 100 females per trap were randomly selected. Conversely, all females were dissected if the number of captured females were equal 
to or less than 100. Flies were classified as gravid if the ovaries contained mature eggs (stage VIII), while those with ovaries of a younger stage (I-VII) were categorized as non-gravid, based on the criteria previously described [22]. The parity was categorized as parous (females that have ever laid eggs) or nulliparous (females that have never laid eggs) by the presence or absence of yellow follicular relics (the remnants of the nurse cells and follicular epithelium which are retained in the ovarioles after oviposition) in the pedicel at the base of ovarioles (Fig. 2) [23]. When females have follicular relics in the pedicels of their ovarioles they were classified as parous; females lacking these follicular relics were classified as nulliparous. Additionally, the number of ovarioles big enough to count, and/or the number of mature eggs in their ovaries were counted and recorded.

\section{Statistical analysis}

To normalize the abundance, $C$. megacephala numbers (x) were transformed into $\log _{10}(x+1)$ prior to statistical analysis. Since only small numbers of flies were collected during the night, the data were analyzed separately between day traps (diurnal flight activity: from 06:00 to 18:00 h) and night traps (nocturnal flight activity: from 18:00 to 06:00 h). The effects of temperature and relative humidity on trap catches during the daytime were assessed using one-way analysis of variance (ANOVA), followed by a Games-Howell post-hoc test. For the patterns of diurnal flight activity, one-way ANOVA and Dunnett's T3 post-hoc test was used to compare differences in the average number of flies caught between time of day (06:00 to 09:00 h, 09:00 to $12: 00 \mathrm{~h}, 12: 00$ to $15: 00 \mathrm{~h}$, and 15:00 to $18: 00 \mathrm{~h}$ ), using the combined number of flies caught at each study site. Spearman's rank correlation coefficient $\left(r_{s}\right)$ was used to determine the influence of climatic factors (temperature, relative humidity and rainfall) on fly density and fecundity. Differences in the average number of ovarioles between seasons and study sites were tested using one-way ANOVA and Games-Howell post-hoc tests. Mann-Whitney U-test was used to compare the abundance of sexes (males and females) and the reproductive status of females, i.e. ovarian status (gravid and non-gravid) and parity status (parous and nulliparous). Pearson's Chi-square test was performed to assess the correlation between the parity status of females and seasons and study sites. Statistical analyses were performed using SPSS software version 17.0 for Windows (SPSS Inc., Chicago, Illinois, USA). All statistical tests were considered significant at the $P<0.05$ level.

\section{Results}

\section{Abundance of C. megacephala}

Altogether 88,273 C. megacephala were sampled during day and night at all three study sites. The highest number of $C$. megacephala were captured in the forest area $(n=31,873$; $36.1 \%)$, followed by the palm plantation $(n=31,347 ; 35.5 \%)$ and longan orchard $(n=25,053 ; 28.4 \%)$. During daytime many more $(n=82,800 ; 93.8 \%)$ specimens were sampled than during night $(n=5473 ; 6.2 \%)$.

\section{Seasonal diurnal activity of $C$. megacephala}

To assess the overall seasonal changes in abundance of C. megacephala, data from each study site were combined. Chrysomya megacephala was perennial in the studied sites (Fig. 3). The seasonal trend of the total number captured in these study areas showed that high numbers of flies were trapped in the summer with a peak in April 2014, before populations decreased rapidly at the end of summer (May 2014), rising again in the early rainy season (June 2014), and eventually declined through the rainy season and winter. During the sampling period, peak numbers of flies were found in April $2014(n=20,673)$, while being lowest in January
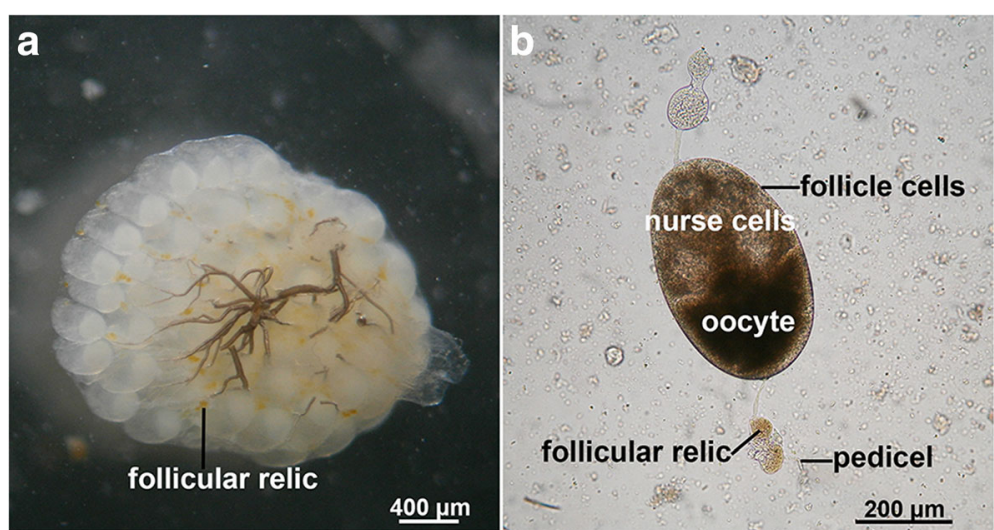

Fig. 2 Photomicrograph of yellow follicular relics from a parous female. a Ovary contains bright yellow follicular relics in the pedicels at the base of the ovarioles. $\mathbf{b}$ Morphological features of ovariole with yellow follicular relic in the pedicel 


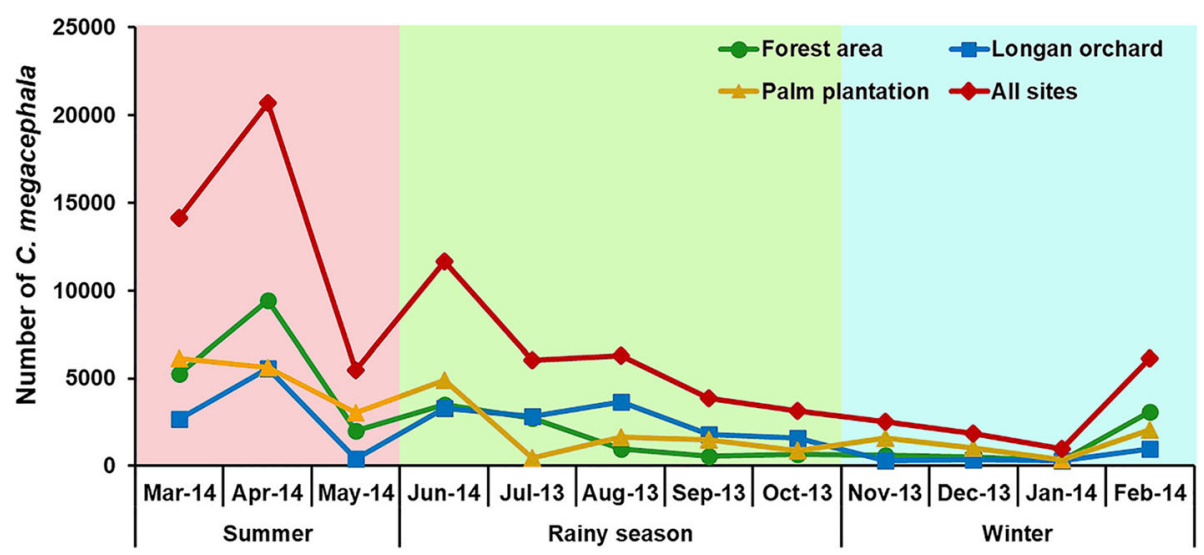

Fig. 3 Seasonal fluctuation in population density of C. megacephala collected by day traps from July 2013 to June 2014

2014 $(n=962)$. A similar trend was noticed in all three study sites (Fig. 3).

The abundance of females $(n=58,188)$ was significantly higher than males $(n=24,612)$ at all three study sites (Mann-Whitney U-test: $U=24362.500, Z=-8.571$, $P<0.0001)$, with an overall female to male sex ratio of 2.36:1.

\section{Influence of climatic factors and ecotypes on fly density}

Spearman's correlation analysis showed that overall, $C$. megacephala abundance was moderately positively correlated with temperature (Spearman's correlation: $r_{s}=0.476, P$ $<0.0001$ ), but moderately negatively correlated with relative humidity (Spearman's correlation: $r_{s}=-0.411, P<0.0001$ ) (Table 1, Fig. 4). The correlation between the climatic factors of each study site and its related fly abundance is shown in Table 1. In all three study sites, fly population showed a positive correlation with temperature, but a negative correlation with relative humidity. During the sampling period, $C$. megacephala was sampled at temperatures between 13.7$51.5{ }^{\circ} \mathrm{C}$, and a relative humidity between $20.8-96.8 \%$ (Fig. 5). Statistical analysis revealed that the highest abundance occurred at temperatures $>35{ }^{\circ} \mathrm{C}$ and relative humidity $<50 \%$ (Game-Howell, $P<0.05$ ), while at temperatures $<25^{\circ} \mathrm{C}$ and relative humidity $>70 \%$ the abundance was lowest (Game-Howell, $P<0.05$ ) (Table 2).
Spearman's correlation analysis revealed a correlation of fly density and weather station temperature, relative humidity and actual rainfall. There was a moderate positive correlation between fly density and temperature (Spearman's correlation: $r_{s}=0.444, P<0.0001$ ), while there was a weakly negative correlation with relative humidity (Spearman's correlation: $r_{s}=-0.307, P<0.0001$ ). There was no correlation between fly density and actual rainfall (Spearman's correlation: $r_{s}=-0.049, P=0.404$ ).

\section{Daily flight activity of $C$. megacephala}

A total of 82,800 flies were collected by day traps $(06: 00$ to $18: 00 \mathrm{~h}$ ) with most of the specimens collected in the afternoon period from $12: 00$ to $18: 00 \mathrm{~h}(68.1 \%$ of the total caught) (Table 3). This pattern of diurnal activity was different between seasons (Table 3, Fig. 6). In summer (Fig. 6a), although high numbers of flies were caught between 15:00 to $18: 00 \mathrm{~h}$, the average numbers captured during the intervals were not significantly different (ANOVA: $F_{(3,32)}=1.616, P=0.205$ ). In the rainy season (Fig. 6b) and winter (Fig. 6c), the average fly numbers captured from 12:00 to $15: 00 \mathrm{~h}$ and 15:00 to 18:00 h (Dunnett T3, $P>0.05$ ) were significantly higher than those captured from 06:00 to 09:00 $\mathrm{h}$ and 09:00 to 12:00 h (Dunnett T3, $P<0.05$ ).

Few $C$. megacephala $(n=5473)$ were collected at night (18:00 to 06:00 h). Small numbers were captured in the

Table 1 Spearman's rank correlation coefficient values of climatic factors and fly density of C. megacephala

\begin{tabular}{|c|c|c|c|c|c|}
\hline & & \multicolumn{4}{|l|}{ Study sites } \\
\hline & & Forest area & Longan orchard & Palm plantation & All sites \\
\hline \multirow[t]{2}{*}{ Temperature } & $r_{s}$ & 0.507 & 0.468 & 0.444 & 0.476 \\
\hline & $P$ & $<0.0001$ & $<0.0001$ & $<0.0001$ & $<0.0001$ \\
\hline \multirow[t]{2}{*}{ Relative humidity } & $r_{s}$ & -0.545 & -0.289 & -0.382 & -0.411 \\
\hline & $P$ & $<0.0001$ & 0.004 & $<0.0001$ & $<0.0001$ \\
\hline
\end{tabular}




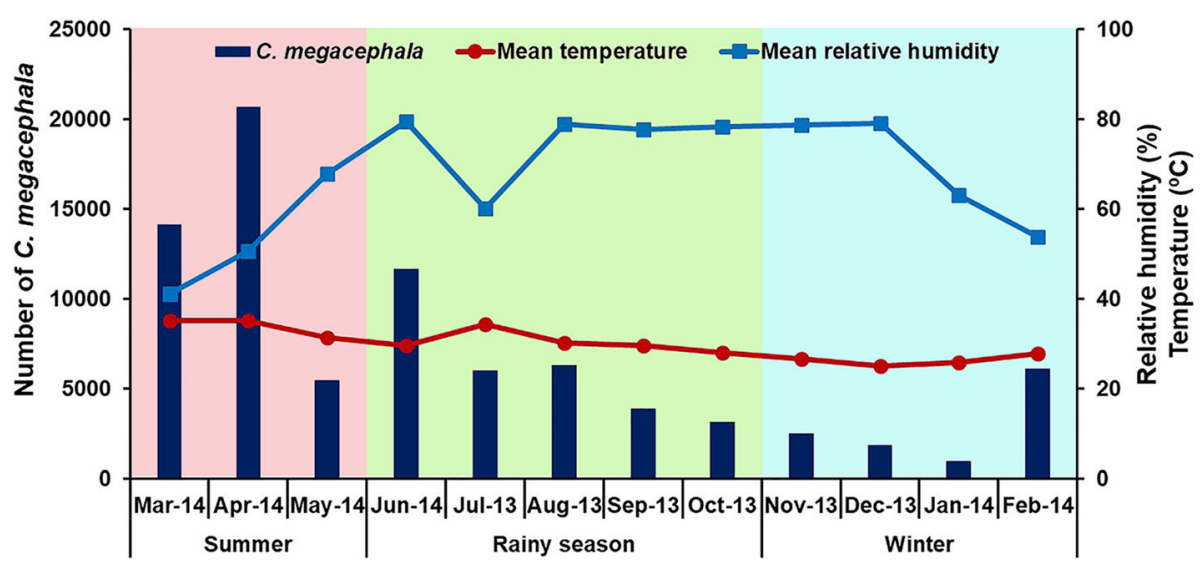

Fig. 4 Fluctuation of the overall C. megacephala population density relative to temperature and relative humidity recorded at the study sites from July 2013 to June 2014

summer and rainy season when sunset was after 18:00 $\mathrm{h}$ and sunrise before 06:00 h. No flies were captured in winter while sunset was before 18:00 h and sunrise after 06:00 h (Fig. 7).

\section{Fecundity and reproductive status of $C$. megacephala females}

Analysis of seasonal fecundity showed that the highest and lowest numbers of ovarioles was 190.9 (June 2014) and 151.0 (March 2014), respectively (Fig. 8). The number of ovarioles statistically differed among seasons, with the average number in the rainy season being significantly higher than in winter and summer (Game-Howell, $P<0.05$ ) (Table 4). No significant differences in ovariole quantity were observed between the three study sites (ANOVA: $\left.F_{(2,2375)}=0.499, P=0.607\right)$. Spearman's correlation analysis showed that the number of ovarioles obtained from all three study sites was not correlated with temperature (Spearman's correlation: $r_{s}=-0.027, P=0.188$ ), and weakly positively correlated with relative humidity (Spearman's correlation: $r_{s}=0.131, P<0.0001$ ).

Of the total 21,065 female C. megacephala dissected, $49.4 \%$ were non-gravid and nulliparous, $42.2 \%$ non-gravid and parous, $6.3 \%$ gravid and nulliparous and $2.1 \%$ gravid and parous. Non-gravid females $(n=19,299$; 91.6\%) were significantly higher in numbers than gravid specimens $(n=1766 ; 8.4 \%)$ (Mann-Whitney U-test: $U=22342.500, Z=-15.363, P<0.0001)$. When analyzing the parity status of the flies, $55.8 \%(n=11,749)$ were nulliparous and therefore occurred significantly more frequently than parous females $(n=9316 ; 44.2 \%)$ (Mann-Whitney U-test: $U=54523.000, Z=-3.692$, $P<0.0001)$. The seasonal fluctuation of parity status is shown in Fig. 9. The number of nulliparous and parous obtained from all three study sites showed that there were more nulliparous than parous females throughout the

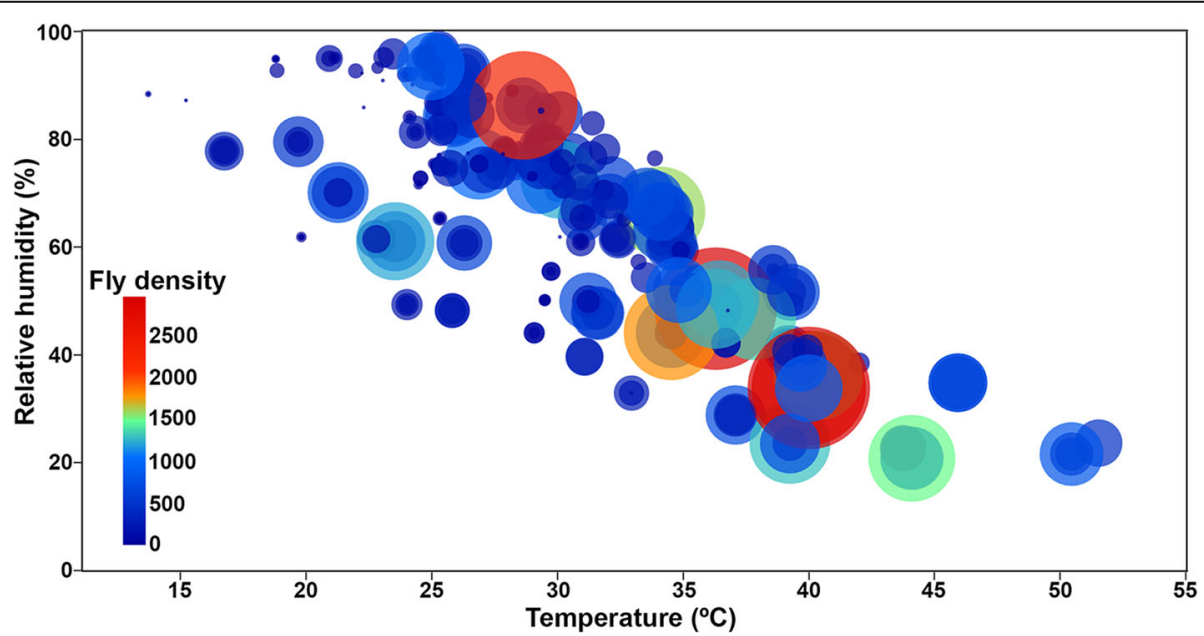

Fig. 5 The number of captured C. megacephala in relation to study site temperature $\left({ }^{\circ} \mathrm{C}\right)$ and relative humidity $(\%)$. Each bubble shows fly density in each temperature and relative humidity recorded in each trap catch; a bigger size of bubble shows a greater number of captured flies 
Table 2 Abundance of C. megacephala collected by day traps in each range of temperature and relative humidity. Different letters indicate significant differences (Game-Howell post-hoc test, $P<0.05)$

\begin{tabular}{lll}
\hline Variable & $n$ & Number of flies* \\
\hline $\begin{array}{l}\text { Temperature }\left({ }^{\circ} \mathrm{C}\right) \\
<25\end{array}$ & 57 & $1.39 \pm 0.92^{\mathrm{a}}$ \\
$25-30$ & 99 & $1.88 \pm 0.65^{\mathrm{b}}$ \\
$30-35$ & 81 & $2.12 \pm 0.73^{\mathrm{b}}$ \\
$>35$ & 51 & $2.57 \pm 0.54^{\mathrm{c}}$ \\
One-way ANOVA & & $F_{(3,284)}=26.034, P<0.0001$ \\
Relative humidity (\%) & & \\
$<50$ & 64 & $2.49 \pm 0.65^{\mathrm{a}}$ \\
$50-70$ & 68 & $2.06 \pm 0.70^{\mathrm{b}}$ \\
$>70$ & 156 & $1.72 \pm 0.80^{\mathrm{c}}$ \\
One-way ANOVA & & $F_{(2,285)}=24.458, P<0.0001$ \\
\hline
\end{tabular}

Abbreviation: $n$, the number of samplings falling into each range of temperature and relative humidity obtained in a one-year study

${ }^{*}$ Mean of $\log _{10}(x+1) \pm S D$

year, except in the months April and June 2014, which showed higher numbers of parous than nulliparous flies (Fig. 9). The parity status was significantly correlated with season (Pearson's Chi-square test: $\chi^{2}=129.737, d f=2$, $P<0.0001)$. Nulliparous flies were proportionally more abundant than parous in all seasons (Table 4). However, no significant correlation of the parity status with study site was shown (Pearson's Chi-square test: $\chi^{2}=0.752, d f=2$, $P=0.687)$.

\section{Discussion}

Understanding the bionomics of blow flies is imperative as one of the key pieces of information to be integrated in fly control strategies, if targeted at the right place, at the right time, with the right approach. Based on the sampling of 88,273 specimens, this work presents significant data on C. megacephala, highlighting comprehensive daily and seasonal activity year-round in three different ecotypes, correlating fly density with various abiotic factors, and evaluating the reproductive potential of field-collected specimens.
Chrysomya megacephala had the highest abundance in summer, peaking in April 2014, and gradually declined during rainy season and winter. Similar findings were reported in earlier studies in Thailand [12, 18]. By comparison, Phasuk et al. [19] showed that C. megacephala had trimodal peaks, with the highest abundance in January, followed by September and June. Seasonal abundance of blow flies studied in India by Wall et al. [24] found that population of $C$. megacephala increased at the beginning of rainy season, and then declined in the dry hot season. In Brazil, the greatest constant abundance of C. megacephala occurred between October and February (end of spring and all of summer) and reached the highest population peak in December (highest temperatures of the year) $[17,25]$. Such information indicated that fluctuation in $C$. megacephala abundance is specific to the location and the population changes according to season. In this regard, investigation on seasonal activity should be carried out in several regions for effective fly control strategy in that specific area.

Higher numbers of trapped females than males suggest that females were active in searching for a protein food source, oviposition, and/or breeding places, while males are not attracted to protein sources for physiological requirements, but for mating needs [26-28]. Similar findings were shown in other studies, collecting more females from meat-baited trap than males [12, 18, 19, 24].

Blow fly density was significantly influenced by climatic factors. Our results clearly showed that C. megacephala density is positively correlated with temperature and negatively correlated with relative humidity. Such results indicated that $C$. megacephala density increased when the temperature was high and the relative humidity was low, as the highest abundance was observed in summer when the temperature was high and the relative humidity low. In contrast, $C$. megacephala abundance was low in the rainy season and winter when the temperature was low and relative humidity high. Therefore, variations in the temperature and relative humidity had significant effects on the abundance and seasonal fluctuation of $C$. megacephala in this studied area. This finding is in agreement with the previous report on the

Table 3 Number of C. megacephala collected by day traps. Different letters in the same column indicate significant differences (Dunnett T3 post-hoc test, $P<0.05$ )

\begin{tabular}{|c|c|c|c|c|}
\hline \multirow{2}{*}{$\begin{array}{l}\text { Sampling time } \\
\text { periods, } \mathrm{h}\end{array}$} & \multirow[t]{2}{*}{ All seasons } & \multicolumn{3}{|l|}{ Season } \\
\hline & & Summer & Rainy season & Winter \\
\hline 6:00-9:00 & $2.08 \pm 0.78^{a}$ & $2.81 \pm 0.31^{\mathrm{a}}$ & $2.13 \pm 0.51^{a}$ & $1.48 \pm 0.84^{\mathrm{a}}$ \\
\hline 9:00-12:00 & $2.31 \pm 0.53^{\mathrm{ab}}$ & $2.69 \pm 0.57^{a}$ & $2.27 \pm 0.42^{\mathrm{a}}$ & $2.07 \pm 0.52^{\mathrm{ab}}$ \\
\hline 12:00-15:00 & $2.65 \pm 0.36^{b}$ & $2.77 \pm 0.42^{a}$ & $2.77 \pm 0.25^{b}$ & $2.40 \pm 0.32^{b}$ \\
\hline 15:00-18:00 & $2.65 \pm 0.62^{b}$ & $3.14 \pm 0.53^{\mathrm{a}}$ & $2.61 \pm 0.69^{\mathrm{ab}}$ & $2.35 \pm 0.36^{b}$ \\
\hline One-way ANOVA & $F_{(3,140)}=7.818, P<0.0001$ & $F_{(3,32)}=1.616, P=0.205$ & $F_{(3,56)}=5.317, P=0.003$ & $F_{(3,44)}=6.952, P=0.001$ \\
\hline
\end{tabular}

Data are presented as mean of $\log _{10}(x+1) \pm$ SD for each time interval obtained from monthly data from each of three study sites in a one-year study 


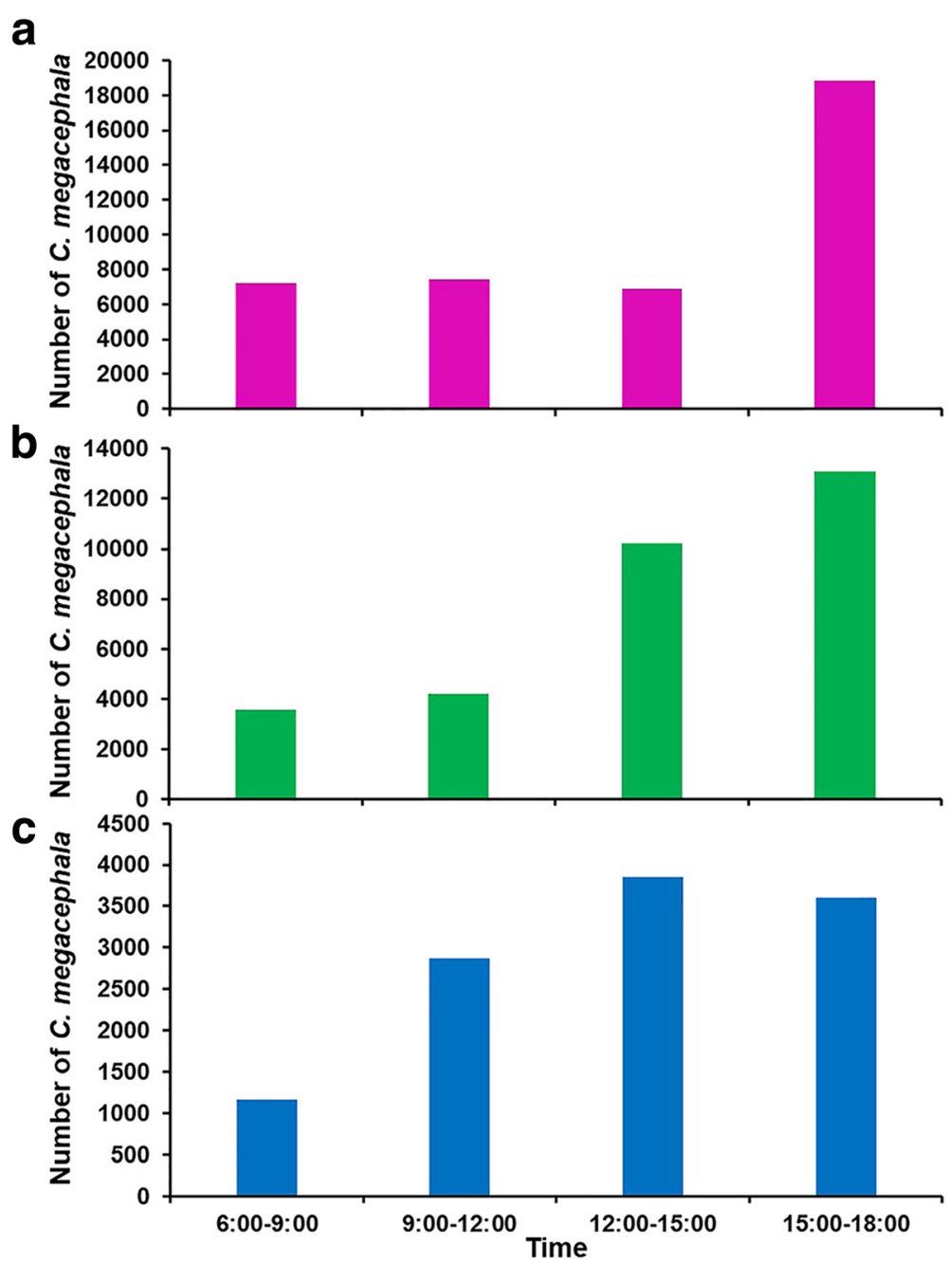

Fig. 6 Diurnal flight activity of the overall C. megacephala population density in summer (a), rainy season (b) and winter (c) from July 2013 to June 2014

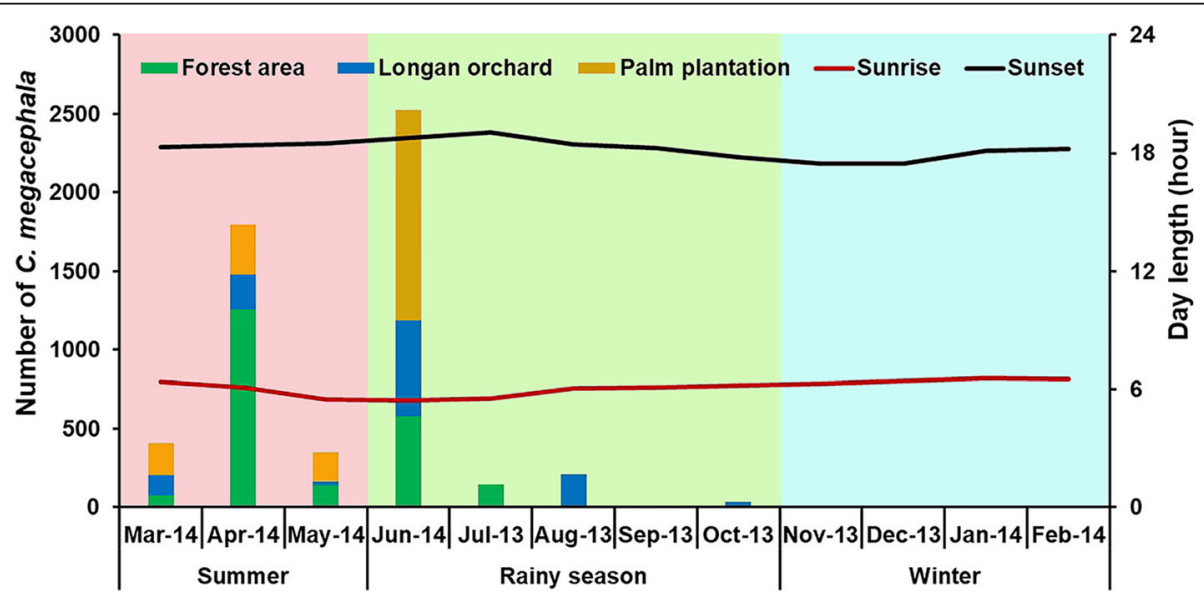

Fig. 7 Seasonal density of C. megacephala collected by night traps from July 2013 to June 2014 


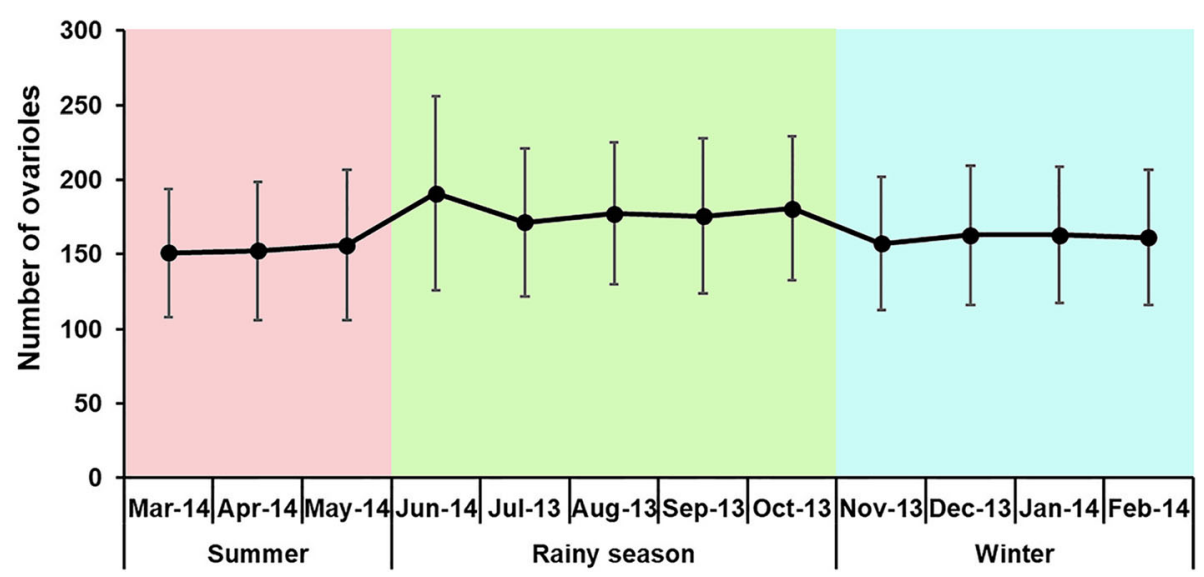

Fig. 8 Seasonal variation of fecundity of C. megacephala females collected from July 2013 to June 2014. Data are presented as mean \pm SD

same species in Thailand by Ngoen-klan et al. [12]. However, it is in contrast with the finding of Phasuk et al. [19] which showed a negative correlation of fly density with temperature and relative humidity. In India, $C$. megacephala abundance was positively associated with relative humidity, but negatively associated with temperature and rainfall [24]. In Brazil, C. megacephala density was positively related to temperature and rainfall [17]. In addition to temperature and relative humidity, our results for the north of Thailand clearly show that the abundance of $C$. megacephala is not correlated with rainfall, which is in contrast with findings in India [24] and Brazil [17, 25].

Among environmental factors, temperature has been considered essential as a factor in blow fly biology since it can directly impact the development, survival, longevity, behavior and population dynamics of flies [12, 29-31]. In the current study, C. megacephala was trapped between 13.7 and $51.5{ }^{\circ} \mathrm{C}$, with the highest number of flies occurring at temperatures $>35^{\circ} \mathrm{C}$. Such results indicate that $C$. megacephala is able to adapt to a broad range of temperatures, with adult activity most intense at high temperature and reduced at lower temperatures. This is in agreement with detailed studies by Ngoen-klan et al. [12] who found C. megacephala at temperatures ranging from 15 to $40^{\circ} \mathrm{C}$, with a high peak in the late summer (high temperature) and low peak in the rainy season and winter (low temperature). In addition, Sukontason et al. [29] revealed that C. megacephala larvae developed rapidly in April $\left(31.4{ }^{\circ} \mathrm{C}\right)$ and grew slowly in the rainy season and winter. Other studies also showed that $C$. megacephala developed more rapidly with increasing temperatures, but developed slowly at low temperatures [30-32].

Blow flies are considered to be diurnal insects and inactive at night [20,33, 34]. However, some studies found nocturnal activity and even oviposition in blow flies [35-37]. In the current study, C. megacephala exhibited a diurnal activity, with a peak in the afternoon (12:00 to 18:00 h). However, the small-scale diurnal activity pattern of flies regarding the time of the day differs across seasons. Minimal numbers of C. megacephala were captured during nighttime. This is in accordance with Nazni et al. [38], who also demonstrated that C. megacephala exhibited both diurnal and nocturnal activities, but much higher numbers of flies in daytime traps than nighttime traps. Conversely, Sucharit \& Tumrasavin [20] stated an activity peak of C. megacephala at 16:00 to 18:00 h, and no flies during the night, as well as Soares \& Vasconcelos [39], who observed neither nocturnal activity nor oviposition during nighttime. In the present study, minimal numbers of flies were captured during nighttime in

Table 4 Fecundity and parity status of C. megacephala females in each season. Different letters indicate significant differences (Game-Howell post-hoc test, $P<0.05$ )

\begin{tabular}{|c|c|c|c|c|c|}
\hline \multirow[t]{2}{*}{ Season } & \multicolumn{2}{|l|}{ Fecundity } & \multicolumn{3}{|l|}{ Parity status } \\
\hline & No. of females counted & No. of ovarioles (mean \pm SD) & Nulliparous, n (\%) & Parous, n (\%) & Total, $n(\%)$ \\
\hline Summer & 673 & $154.5 \pm 45.8^{\mathrm{a}}$ & $3853(50.8)$ & $3731(49.2)$ & $7584(100)$ \\
\hline Rainy season & 1036 & $178.2 \pm 54.1^{b}$ & $5410(57.6)$ & $3977(42.4)$ & $9387(100)$ \\
\hline Winter & 669 & $163.7 \pm 46.0^{c}$ & $2486(60.7)$ & $1608(39.3)$ & $4094(100)$ \\
\hline Total & 2378 & $F_{(2,2375)}=49.214, P<0.0001$ & $11,749(55.8)$ & $9316(44.2)$ & $21,065(100)$ \\
\hline
\end{tabular}




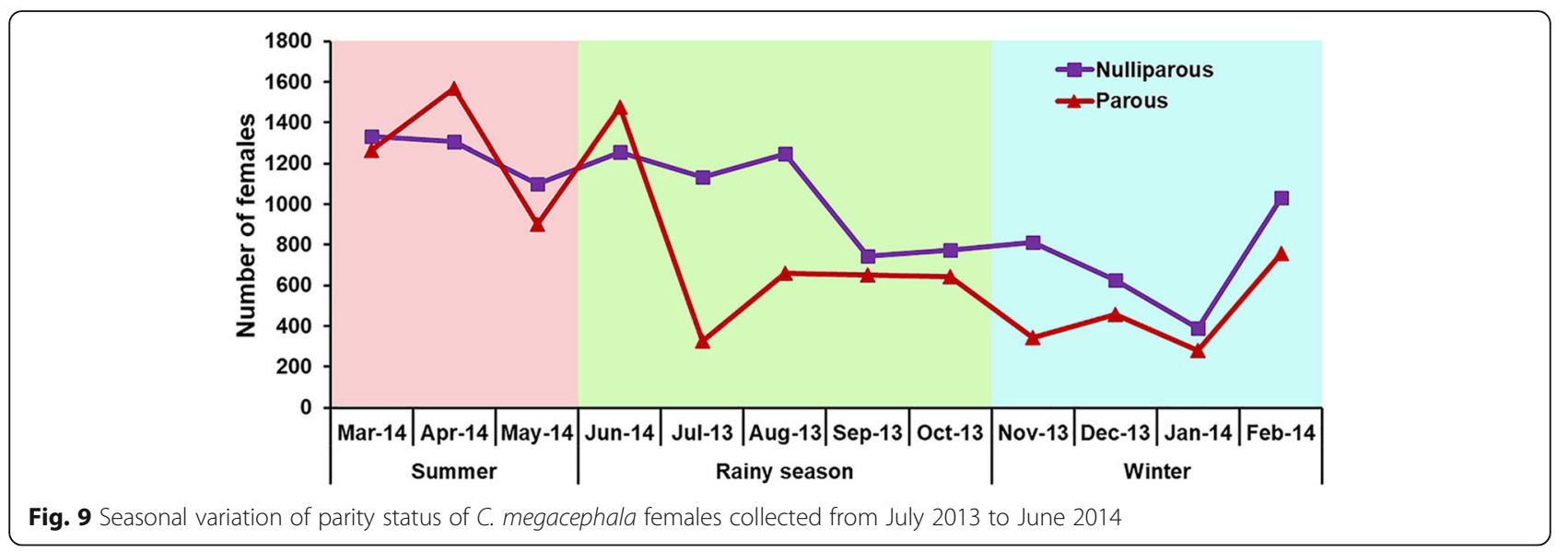

summer and rainy season as the sunset was after 18:00 $\mathrm{h}$ (nighttime trap was set from 18:00 to 06:00 h), thus flies were still able to be active, entering the traps. In contrast, no flies were captured in the night in the winter as the sunset was before 18:00 h. Such results suggest that light might stimulate fly activity [40, 41], as reported by Sucharit \& Tumrasavin [20], who found that no flies were collected after sunset.

Fecundity plays an important role in population dynamics since it determines the population growth potential [42]. In the present study, we found fecundity was significant differences between seasons; however, fecundity showed no relationship with temperature and just a very weak positive correlation with relative humidity. Similar findings were observed for C. megacephala [43], and other blow fly species like Chrysomya albiceps [44] and Lucilia eximia [45], which fecundity was not significantly affected by changes in temperature. This result suggested that fecundity is probably influenced by the ecological niches occupied by this species, which seasonal and environmental changes may affect the abundance of food resources, e.g. the presence of plants, fruits, animal carcasses or dung. Many studies have revealed that the larval nutrition plays a key role in life-history characters in insects such as growth, survival, body size, longevity and reproduction [46-49]. The fitness of a female fly is determined by the number of offspring that she can produce, which depends on her body size. Study on the relationship between fecundity and body size of three blow fly species (C. megacephala, C. albiceps and L. eximia) in Brazil revealed that fecundity was positively correlated with body size [43-45], indicating that fecundity increased when the body size was large.

Determination of the age structure of adult blow flies in the field is essential for understanding their ecology and behavior which vary with age [27, 50-52]. Our results showed that many more females were non-gravid than gravid, and more nulliparous than parous. This finding is consistent with those of Spradbery [27] and Davies [52]. This should be considered when planning a sound fly control program, which e.g. applying targeted control measures before the population reaches peaks of gravidity and reproduction. From a forensic point of view, it is of interest that gravid blow fly females are much more attracted by stages of initial decay, while non-gravid flies were much more present during advanced decay [51]. Different ages affect the behavior of blow flies, e.g. as non-gravids required a protein food for egg maturation, while gravid specimens required protein food for egg deposition. In the present study, trapped females showed a marked bias in ovarian status, females were mostly non-gravid, suggesting that meat-baited traps act as a protein source rather than as an oviposition site.

As for the parity determination, most non-gravid dissected flies from all sites were nulliparous, indicating the newly emerged young fly populations. Conversely, the presence of follicular relics in the ovaries provides a rough estimate of the female age; therefore, parous females are only classified as old flies. The majority of dissected females were nulliparous rather than parous, indicating much younger flies than older in the studied areas. Such result suggested trap bias in parity status of females. This was probably due to the greater protein requirements to begin ovarian development and mating needs in nulliparous females compared to parous females, which had previous exposure to protein and were mated. As previously reported in L. sericata [53], females that had recently oviposited showed a lower attractive response to liver odor than protein-deprived or fully gravid females. Moreover, parity status appears to be related to seasons, suggesting that seasonality affects reproductive activity of $C$. megacephala females. 


\section{Conclusions}

Our results demonstrated that temperature and relative humidity significantly influenced the abundance of $C$. megacephala. Chrysomya megacephala was found year-round, with maximum abundance in summer. Furthermore, the patterns of diurnal flight activity differed between seasons and time of day, with peak activity occurring from 06:00 to $18: 00 \mathrm{~h}$ in summer and 12:00 to 18:00 $\mathrm{h}$ in the rainy season and winter. Our findings provide an insight into essential bionomics, which can be useful for designing effective fly control strategies, in terms of when to implement control programs. Moreover, the results regarding the reproductive potential and age structure of females obtained in this study might also help to predict fly activity and oviposition in a forensic context, helping to evaluate the time since death.

\section{Abbreviations}

$\mathrm{PMI}_{\min }$ : Minimum time since death; ANOVA: Analysis of variance; SPSS: Statistical Package for the Social Sciences

\section{Acknowledgments}

We thank the Department of Geography, Faculty of Social Science, Chiang Mai University, Thailand for geographical data. We thank the Faculty of Agriculture, Chiang Mai University, and the staff at Mae Hia Agricultural Research, Demonstrative and Training Center, Chiang Mai, Thailand: Songchao Insomphun, Tupthai Norsuwan and Kanong Chaikheow, for facilitating us during the experimental period. Part of this work has been presented in the 8th International Congress of Dipterology, held in Potsdam, Germany, during 10-15 August 2014

\section{Funding}

This research was financially supported by the Thailand Research Fund through the Royal Golden Jubilee Ph.D. Program (PHD/0118/2556 to KLS and NS and PHD/0246/2550 to KLS and TK-k); the Diamond Research Grant from the Faculty of Medicine, Chiang Mai University; and Chiang Mai University (CMU) through the Excellence Center for Insect Vector Study.

\section{Availability of data and materials}

The data supporting the conclusions of this article are included within the article.

\section{Authors' contributions}

NS conducted the fieldwork, identified specimens, analyzed the data and drafted the manuscript. TK-k, SS and CS conducted the fieldwork and identified specimens. KLS, KS, PS and ST supervised the study, provided advice for study design and implementation, and wrote the manuscript. JA provided advice and revised the manuscript. All authors read and approved the final manuscript.

\section{Ethics approval and consent to participate}

Not applicable.

\section{Consent for publication}

Not applicable.

\section{Competing interests}

The authors declare that they have no competing interests.

\section{Publisher's Note}

Springer Nature remains neutral with regard to jurisdictional claims in published maps and institutional affiliations.

\section{Author details}

${ }^{1}$ Graduate School, Chiang Mai University, Chiang Mai 50200, Thailand.

${ }^{2}$ Department of Parasitology, Faculty of Medicine, Chiang Mai University,
Chiang Mai 50200, Thailand. ${ }^{3}$ Department of Plant Science and Natural Resources, Faculty of Agriculture, Chiang Mai University, Chiang Mai 50200, Thailand. ${ }^{4}$ Institute of Legal Medicine, Goethe-University Frankfurt, Kennedyallee 104, 60596 Frankfurt am Main, Germany.

Received: 15 February 2018 Accepted: 29 June 2018

Published online: 13 July 2018

\section{References}

1. Greenberg B. Flies and disease. Biology and disease transmission. Vol. 2. New Jersey: Princeton University Press; 1973.

2. Sulaiman S, Sohadi AR, Yunus $H$, Iberahim R. The role of some cyclorrhaphan flies as carriers of human helminths in Malaysia. Med Vet Entomol. 1988;2:1-6.

3. Monzon RB, Sanchez AR, Tadiaman BM, Najos OA, Valencia EG, de Rueda RR, et al. A comparison of the role of Musca domestica (Linnaeus) and Chrysomya megacephala (Fabricius) as mechanical vectors of helminthic parasites in a typical slum area of Metropolitan Manila. Southeast Asian J Trop Med Public Health. 1991;22:222-8.

4. Fernandes LF, Pimenta FC, Fernandes FF. First report of human myiasis in Goiás state, Brazil: frequency of different types of myiasis, their various etiological agents, and associated factors. J Parasitol. 2009;95:32-8.

5. Ferraz ACP, Proença B, Gadelha BQ, Faria LM, Barbalho MGM, Aguiar-Coelho VM, et al. First record of human myiasis caused by association of the species Chrysomya megacephala (Diptera: Calliplioridae), Sarcophaga (Liopygia) ruficornis (Diptera: Sarcophagidae), and Musca domestica (Diptera: Muscidae). J Med Entomol. 2010;47:487-90.

6. Amendt J, Richards CS, Campobasso CP, Zehner R, Hall MJR. Forensic entomology: applications and limitations. Forensic Sci Med Pathol. 2011; 7:379-92.

7. Sukontason K, Narongchai P, Kanchai C, Vichairat K, Sribanditmongkol P, Bhoopat $T$, et al. Forensic entomology cases in Thailand: a review of cases from 2000 to 2006. Parasitol Res. 2007:101:1417-23.

8. Abdullah SR, Omar B, Salleh AFM, Othman H, Wahid SA. Comparative fly species composition on indoor and outdoor forensic cases in Malaysia. J Forensic Leg Med. 2017:45:41-6.

9. Verves YG. A catalogue of Oriental Calliphoridae (Diptera). Int J Dipterol Res, 2005;16:233-310.

10. Tumrasvin W, Kurahashi $H$, Kano R. Studies on medically important flies in Thailand VII. Report on 42 species of calliphorid flies, including the taxonomic keys (Diptera: Calliphoridae). Bull Tokyo Med Dent Univ. 1979:26:243-72.

11. Moophayak K, Klong-klaew T, Sukontason K, Kurahashi H, Tomberlin JK, Sukontason KL. Species composition of carrion blow flies in northern Thailand: altitude appraisal. Rev Inst Med Trop Sao Paulo. 2014;56:179-82.

12. Ngoen-klan R, Moophayak K, Klong-klaew T, Irvine KN, Sukontason KL, Prangkio C, et al. Do climatic and physical factors affect populations of the blow fly Chrysomya megacephala and house fly Musca domestica? Parasitol Res. 2011;109:1279-92.

13. Klong-klaew T, Sontigun N, Sanit S, Samerjai C, Sukontason K, Kurahashi H, et al. Field evaluation of a semi-automatic funnel trap targeted the medically important non-biting flies. Acta Trop. 2017:176:68-77.

14. Sukontason KL, Bunchoo M, Khantawa B, Piangjai S, Rongsriyam Y, Sukontason K. Comparison between Musca domestica and Chrysomya megacephala as carriers of bacteria in northern Thailand. Southeast Asian J Trop Med Public Health. 2007:38:38-44.

15. Chaiwong T, Srivoramas T, Sukontason K, Sanford MR, Sukontason KL. Bacterial fauna associated with the blow fly, Chrysomya megacephala (F.) in Ubon Ratchathani Province of northeast Thailand. Int J Parasitol Res. 2012:4:71-4.

16. Srivoramas T, Chaiwong T, Sanford MR. Isolation of fungi from adult house fly; Musca domestica and the blow fly Chrysomya megacephala in Ubon Ratchathani Province, northeastern Thailand. Int J Parasitol Res. 2012;4:53-6.

17. Pires EM, Carraro VM, Zanuncio JC. Seasonal abundance of Chrysomya megacephala and C. albiceps (Diptera: Calliphoridae) in urban areas. Rev Colomb Entomol. 2008;34:197-8.

18. Lertthamnongtham S, Sukontason KL, Sukontason K, Piangjai S, Choochote W, Vogtsberger RC, et al. Seasonal fluctuations in populations of the two most forensically important fly species in northern Thailand. Ann Trop Med Parasitol. 2003;97:87-91. 
19. Phasuk J, Tharawoot T, Chanpaisaeng J. Seasonal abundance of blow flies (Diptera: Calliphoridae) in three urban parks of Bangkok, Thailand. Kasetsart J (Nat Sci). 2013;47:828-34.

20. Sucharit S, Tumrasvin W. The diurnal activities of Musca domestica Linnaeus and Chrysomyia megacephala Fabricius in Bangkok. Jap J Sanit Zool. 1981; 32:334-6.

21. Kurahashi $\mathrm{H}$, Bunchu N. The blow flies recorded from Thailand, with the description of a new species of Isomyia Walker (Diptera, Calliphoridae). Jpn J Syst Ent. 2011;17:237-78.

22. Chaiwong T, Sukontason K, Chaisri U, Kuntalue B, Vogtsberger RC, Sukontason $\mathrm{KL}$. Ovarian ultrastructure and development of the blow fly, Chrysomya megacephala (Diptera: Calliphoridae). Int J Parasitol Res. 2012;4:65-70

23. Tyndale-Biscoe M. Age-grading methods in adult insects: a review. Bull Entomol Res. 1984;74:341-77.

24. Wall R, Howard JJ, Bindu J. The seasonal abundance of blowflies infesting drying fish in south-west India. J Appl Ecol. 2001;38:339-48.

25. Mello RS, Queiroz MMC, Aguiar-Coelho VM. Population fluctuations of calliphorid species (Diptera, Calliphoridae) in the Biological Reserve of Tinguá, state of Rio de Janeiro, Brazil. Iheringia Sér Zool. 2007;97:481-5.

26. Roberts JA, Kitching RL. Ingestion of sugar, protein and water by adult Lucilia cuprina (Wied.) (Diptera, Calliphoridae). Bull Entomol Res. 1974;64:81-8.

27. Spradbery JP. The reproductive status of Chrysomya species (Diptera: Calliphoridae) attracted to liver-baited blowfly traps in Papua New Guinea. Aust J Entomol. 1979;18:57-61.

28. Mackerras MJ. Observations on the life-histories, nutritional requirements and fecundity of blowflies. Bull Entomol Res. 1993;24:353-62.

29. Sukontason K, Piangjai S, Siriwattanarungsee S, Sukontason KL. Morphology and developmental rate of blowflies Chrysomya megacephala and Chrysomya rufifacies in Thailand: application in forensic entomology. Parasitol Res. 2008;102:1207-16.

30. Yang ST, Shiao SF. Temperature adaptation in Chrysomya megacephala and Chrysomya pinguis, two blow fly species of forensic significance. Entomol Exp Appl. 2014;152:100-7.

31. Yang YQ, Li XB, Shao RY, Lyu Z, Li HW, Li GP, et al. Developmental times of Chrysomya megacephala (Fabricius) (Diptera: Calliphoridae) at constant temperatures and applications in forensic entomology. J Forensic Sci. 2016; 61:1278-84.

32. Gruner SV, Slone DH, Capinera JL, Turco MP. Development of the Oriental latrine fly, Chrysomya megacephala (Diptera: Calliphoridae), at five constant temperatures. J Med Entomol. 2017;54:290-8.

33. Zurawski KN, Benbow ME, Miller JR, Merritt RW. Examination of nocturnal blow fly (Diptera: Calliphoridae) oviposition on pig carcasses in midMichigan. J Med Entomol. 2009;46:671-9.

34. Barnes KM, Grace KA, Bulling MT. Nocturnal oviposition behavior of forensically important diptera in Central England. J Forensic Sci. 2015;60:1601-4.

35. Greenberg B. Nocturnal oviposition behavior of blow flies (Diptera: Calliphoridae). J Med Entomol. 1990;27:807-10.

36. Singh D, Bharti M. Further observations on the nocturnal oviposition behaviour of blow flies (Diptera: Calliphoridae). Forensic Sci Int. 2001;120:124-6.

37. Baldridge RS, Wallace SG, Kirkpatrick R. Investigation of nocturnal oviposition by necrophilous flies in central Texas. J Forensic Sci. 2006;51:125-6.

38. Nazni WA, Nooraidah H, Jeffery J, Azahari AH, Mohd Noor I, Sadiyah I, et al. Distribution and abundance of diurnal and nocturnal dipterous flies in the Federal Territory, Putrajaya. Trop Biomed. 2007;24:61-6.

39. Soares TF, Vasconcelos SD. Diurnal and nocturnal flight activity of blow flies (Diptera: Calliphoridae) in a rainforest fragment in Brazil: implications for the colonization of homicide victims. J Forensic Sci. 2016;61:1571-7.

40. Payne JA. A summer carrion study of the baby pig Sus scrofa Linnaeus. Ecology. 1965;46:592-602.

41. Saunders DS. Circadian rhythms and the evolution of photoperiodic timing in insects. Physiol Entomol. 2009;34:301-8.

42. Godoy WAC, Von Zuben CJ, dos Reis SF, Von Zuben FJ. Dynamics of experimental populations of native and introduced blowflies (Diptera: Calliphoridae): mathematical modelling and the transition from asymptotic equilibrium to bounded oscillations. Mem Inst Oswaldo Cruz. 1996;91:641-8.

43. Reigada C, Godoy WAC. Seasonal fecundity and body size in Chrysomya megacephala (Fabricius) (Diptera: Calliphoridae). Neotrop Entomol. 2005; 34:163-8.

44. Riback TIS, Godoy WAC. Fecundity, body size and population dynamics of Chrysomya albiceps (Wiedemann, 1819) (Diptera: Calliphoridae). Braz J Biol. 2008;68:123-8.
45. Gião JZ, Godoy WAC. Seasonal population dynamics in Lucilia eximia (Wiedemann) (Diptera: Calliphoridae). Neotrop Entomol. 2006;35:753-6.

46. Ujvari B, Wallman JF, Madsen T, Whelan M, Hulbert AJ. Experimental studies of blowfly (Calliphora stygia) longevity: A little dietary fat is beneficial but too much is detrimental. Comp Biochem Physiol Mol Integr Physiol. 2009; 154:383-8.

47. Andersen LH, Kristensen TN, Loeschcke V, Toft S, Mayntz D. Protein and carbohydrate composition of larval food affects tolerance to thermal stress and desiccation in adult Drosophila melanogaster. J Insect Physiol. 2010;56: 336-40.

48. Rabêlo KC, Thyssen PJ, Salgado RL, Araújo MS, Vasconcelos SD. Bionomics of two forensically important blowfly species Chrysomya megacephala and Chrysomya putoria (Diptera: Calliphoridae) reared on four types of diet. Forensic Sci Int. 2011;210:257-62.

49. Li X, Yang Y, Li G, Li H, Wang Q, Wan L. The effect of dietary fat levels on the size and development of Chrysomya megacephala (Diptera: Calliphoridae). J Insect Sci. 2014;14:174.

50. Hayes EJ, Wall R, Smith KE. Mortality rate, reproductive output, and trap response bias in populations of the blowfly Lucilia sericata. Eco Entomol. 1999;24:300-7.

51. Archer MS, Elgar MA. Effects of decomposition on carcass attendance in a guild of carrion-breeding flies. Med Vet Entomol. 2003:17:263-71.

52. Davies L. Lifetime reproductive output of Calliphora vicina and Lucilia sericata in outdoor caged and field populations; flight vs. egg production? Med Vet Entomol. 2006;20:453-8.

53. Ashworth JR, Wall R. Effects of ovarian development and protein deprivation on the activity and locomotor responses of the blowfly, Lucilia sericata, to liver odour. Physiol Entomol. 1995;20:281-5.

\section{Ready to submit your research? Choose BMC and benefit from:}

- fast, convenient online submission

- thorough peer review by experienced researchers in your field

- rapid publication on acceptance

- support for research data, including large and complex data types

- gold Open Access which fosters wider collaboration and increased citations

- maximum visibility for your research: over $100 \mathrm{M}$ website views per year

At BMC, research is always in progress.

Learn more biomedcentral.com/submissions 